typical size and the features which distinguish that species from those with which it might be confused; and notes on habitat and geographical distribution, often with qualitative comments on abundance. Usually there is additional information on what is known of the animal's natural history. Each entry closes with literature citations, sometimes only one or two, in other cases several dozen. Detailed references are then provided at the end of each chapter.

The introduction suggests that this book was intended as a primary guide for identifying the animals, but this emphasis is, I think, misplaced; it will simply not do as a field manual. Its unusual format and sheer weight (about six pounds) militate against carrying the book along to the shore. Beyond the problems of getting book and animal together (since the reader is, rightly, urged not to bring specimens home with him), there are none of the traditional "keys" for identification; and the coverage is intentionally restricted to the more common and conspicuous elements of the fauna, meaning that using the plates and text for primary identification would be not only timeconsuming but often misleading.

For field identification, then, one should instead take along Smith and Carlton's revision of Light's Manual (University of California Press, 1980). Thereafter, Intertidal Invertebrates of California can be treated as something akin to a biographical dictionary. Knowing, or at least having a strong hunch about the name of the creature, the reader can here confirm that he has, indeed, probably seen this or that member of the community, and then learn some of what the experts know about it, as well as where to find further information.

A conspicuous contrast with a biographical dictionary is that no historian is ever likely, on the basis of some arbitrary legal point, to decide that henceforth Madame Curie will be known only as Marie Skladowska. Many of my old friends in the intertidal zone, however, regardless of how well established their reputations were, are now assigned names different from those 1 learned 25 years ago. In some cases (e.g. Mitella polymerus and Aletes squamigerus) the older names are also included in the index to this volume; but for others (e.g. Acmaea digitalis and several congeners, and Lepidopa myops) there is no hint about former identity. This is, of

Cold Spring Harbor Laboratory have recently published the proceedings of the symposium on viral oncogenes which was held last year. The two-volume set of proceedings, comprising Vol. XLIV in the series Symposia on Quantitative Biology, is available from CSHL, Fulfillment Department, PO Box 100, Cold Spring Harbor, NY 11724, or through booksellers, price $\$ 130$ (\$156 outside the USA).

course, not so much a complaint about this book as about the problems inherent in nomenclature, and it can be argued that such changes represent "progress"; but I sometimes wonder. . .

The neophyte will find the chapter introductions and the detailed text entries in this book most useful; the more advanced student will find the literature citations a good starting point for a research project; everyone will, I think, enormously appreciate the coloured plates. The professional biologist who knows some part of the literature on a particular group or species will no doubt note - as I did -

cases of mistaken conclusions, incomplete or outdated citations, and uneveness in coverage. But it would be petty to emphasize such deficiencies. The central point is that this book is an indispensable addition to the library of all who are interested in the common intertidal invertebrates of the California shoreline and it contains a very attractive collection of colour portraits for those who will never get there.

J.T. Enright is Professor of Behavioral Physiology at the Scripps Institution of Oceanography, La Jolla, California.

\title{
Old twists to an old tale
}

\section{Jerry Donohue}

The Double Helix: Text, Commentary, Reviews, Original Papers. Edited by Gunther S. Stent. Pp.298. ISBN hbk 0-297-77899-4; ISBN pbk 0-393-95075-1. (Weidenfeld \& Nicolson/W.W. Norton: 1981.) Hbk £10; pbk $\$ 5.95$.

AN OLD proverb, as given by Gibbon, tells us that "happy is the nation that has no history" ". If this applies to substances, then DNA, surely, is the unhappiest of molecules, for it is the subject of innumerable biographies.

This new book contains: the complete The Double Helix; reprints of 12 reviews of it from 1968 and discussions of these by Gunther Stent; reprints of three papers from Nature by James Watson, Francis Crick and Aaron Klug; three letters to Science from 1968 by Max Perutz, M.H.F. Wilkins and Watson (see below); reprints of six papers from 1953-54 describing the original DNA work done in Cambridge and King's; and a name index the usefulness of which is somewhat marred by careless inaccuracies.

Should the fact that only about $5 \%$ of the contents of this new edition is previously unpublished material be cause for discontent? Probably not, as it brings together The Double Helix and some of the important writings it spawned. There are, however, other causes for discontent which are hardly contentious. The original text of The Double Helix, including the photographs and diagrams, ran to 233 pages; in this reprint these occupy 135 pages. This drastic compression was accomplished by abandoning the elegant format of starting each chapter on a new page; by taking the plates of the first (Signet, 1969) paperback edition, which was itself a compression of the original, and compressing it still further by putting more lines per page; and by reducing the sizes of the photographs, some by more than $50 \%$, so that the individuals in the group photographs are virtually unrecognizable. Also reduced in size is the photographic reproduction of an historic letter of Watson to Delbrück which is legible only with great difficulty and, in some places, totally undecipherable, a circumstance not caused by Watson's crabbed hand. Surely a book as important as this deserves a better production.

Something very mysterious should also be pointed out. In the diagram on p. 111 the enol structure for thymine incorrectly has an oxygen atom where there should be a hydrogen atom. The same diagram on p.191 of the hardback first edition of The Double Helix is correct, and identical in every other respect, right down to the pattern of dots inside the rings of the bases Now, admittedly, some of the early difficulties in cracking the DNA structure concerned the keto-enol business, but what sinister force, in Alexander Haig's terminology, took it upon itself to change a correct structure to an erroneous one?

There are several misconceptions and misreportings that ought to be dispelled before remarking on a few of the reviews included in this new volume.

- The Myth of the Invention of Base Pairing. Throughout the reviews runs the thread of the notion that Watson and Crick would never have discovered their structure had it not been for "rules" of Erwin Chargaff that in DNA (molar amounts of) cytosine $=$ guanine and thymine = adenine. However, Chargaff himself had not yet referred to this relationship as rules, and, indeed, his own published analytical data gave merely the merest hint of these regularities, and he himself averred the possibility that the regularities might be accidental. Stent (pp. 168-169) has more to say on this.

The fault for these misconceptions must be squarely on the shoulders of Watson. We find him writing (p.75) "The moment [Spring 1952] was thus appropriate to think seriously about some curious regularities in DNA chemistry first observed by Chargaff', and then subsequently cheerfully disregarding them, and building a like-with-like, non-complementary, model. In addition, he had been assured by his friend, the biochemist Markham, that if 
Hear the song of how the spiral Complex, twisted, double, chiral Was discovered. Its construction Following some shrewd deduction Was accomplished. From all sides "Oh Tell it as it was" they cried so Then he took his pen and paper And composed the helix caper Writing of the Cambridge popsy Turned the world of science topsy Turvy like had not before been Done. The story is no more than How the structure was discovered Secret of the gene uncovered Biological prediction Better than a work of fiction Stylistically breezy

Everything appeared made easy And it was. The bases' pairing Found at last - a small red herring Notwithstanding. How he found them
And the hydrogens that bound them

Was a stroke more accidental

Than a work experimental

Chemistry was not his calling

He had read one book by Pauling

Models of the bases he'd made

With them on his desk top he'd played

Shuffling them and putting like with

Like he made no lucky strike with

Guanine, thymine, adenine. A

Letter came from Pasadena

Horrors! then the day was won for

Pauling's model was quite done for

Extra atoms he had set in

Where no atoms should be let in

With some phrases less than modest

Pauling's model's called the oddest

Back now to the basic pairing

How's the structure building faring?

Faster, faster goes the race, then

Everything falls into place when
Tautomers which nature chooses Are the ones our author uses

Two chains (but here we can't be sure)

Plus this extra structure feature:

Pauling's outside bases inside

Pauling's inside phosphates outside

Now they all were quite ecstatic

Soon became they quite dogmatic

Having nature's secret later

Checked against the $\mathrm{x}$-ray data

This was difficult, for Rosie

Found our scientist rather nosey

Bragg compares the book with Pepys. Is

This the verdict of Maurice? His

Thoughts alas we cannot gainsay

Trumpet blowing's not his forte

Tales like this do have a moral

Whether printed whether oral

Find the right man to advise you

Then you'll get a Nobel prize too.
Chargaff said that guanine equalled cytosine, he, Markham, was equally certain that it did not, because Chargaff's experimental methods inevitably underestimated the true amount of cytosine. On numerous other occasions Watson refers to Chargaff's "rules".

It is, on the other hand, abundantly clear from the narrative that these "rules" had nothing whatsoever to do with the construction of the DNA model. The model came first, and made the rules, not the other way around.

- The Myth of the Undercover Agent. In some of the reviews selected by Stent the role which Peter Pauling played is displayed as not quite what it should have been. Thus Watson, according to Merton (p.215), reports "with temerity and selfmocking wit the occasions on which Linus Pauling's son, Peter, then a student at Cambridge, became a prime source of information about what his father was up to". Morrison (p.176) says that the idea for the double helix came ". . . out of hearing from the young American expert upstairs [actually, I was not upstairs at all, but in the same office as Bob Parrish, Watson, Crick and Peter] that the textbook was probably wrong, or out of rumors about what Pauling was thinking - relayed by his son Peter at Cambridge"'. Lear (p.195) goes considerably further in stating that Watson "discloses how he used his young friend Peter Pauling to spy on Pauling's brilliant father, Linus". And Lwoff (p.227) observes that "Peter Pauling works in the Cavendish, receives detailed letters from Pasadena and informs his colleagues of the evolution of his father's work".

On careful reading of The Double Helix we find that Watson says nothing of the sort. Consult, if you will, the name index for the citations to verify this, and come to the conclusion that these statements and innuendoes in the reviews are pure fiction. So much for spies!

- The Myth of the Race. Another thread, nay, hawser, which twines through the reviews, is the "breathless race" between Watson and Crick on the one hand, and Linus Pauling on the other, towards that legendary ceremony, established by the dynamite tycoon, in the gloomy, sunless Stockholm of December. The same strand snakes its way through The Double Helix. How, though, can there be a race with only one team and no antagonist? At this stage (1952-1953), Pauling, whose reputation as a scientist was unequalled, had well over 200 publications under his belt, including a dozen or more books universally appreciated and widely read. His ticket to Sweden was long overdue. (He did, in fact, make this journey the very next year in 1954 to collect his first Nobel prize.) Was he racing Watson? Certainly not. To Pauling, in Peter's view (New Scientist, May 31 1973, p.558), DNA was just another chemical, intrinsically equal in interest to, say, sodium chloride; both presented interesting structural problems, so why race with DNA?

- The Myth of the Filched Photographs and the Dipped Data. The fourth and final myth concerns the X-ray data, and whether Watson and Crick came by them by unorthodox methods. Among the reviewers we find Sinsheimer referring to "cadged data" and a "privileged report"', Lear to a "clandestine communication channel"' and supposedly "confidental data", and Merton to "an odd expedient for gaining access to badly needed information". Lwoff and Chargaff (in his review, not included in this volume) quote a crucial paragraph from The Double Helix which led to both of them to comment on ethics. The same passage is reproduced by Perutz, the supposedly clandestine channel, in his letter, pp.207-210, in which, as well in the letters by Wilkins and Watson which follow, it is made abundantly clear that the report was not confidential, and the data had already been disclosed in open seminars.

As a matter of fact, an X-ray diffraction photograph which, although not of the high quality of those produced by the two groups at King's, clearly shows the characteristic helical pattern of the B structure, had been published by Astbury years earlier, so all the fuss over stolen data was really unnecessary.

Five of the reviews of The Double Helix included here were previously reviewed by Gunther Stent, the editor. The article by Chargaff, that vieux terrible of the DNA saga, although not reprinted because he withheld permission, is reviewed. (Anyone wishing to read the original will find it in Science 29 March 1968; p.1448). Of the seven new reviews, one of them warrants comment, that by the bipseudonymenous "F.X.S.", originally “F.R.S.'. This is not a review at all, but verbal virtuosity by a polylingual sesquipedalianist, and why Stent chose to include it is an enigma, as it adds little insight into DNA or those connected with it. F.X.S. is coy about his identity, but really, who cares? His piece is worth reading, but hardly reprinting.

There are numerous other important reviews not included by Stent - by Lord Todd in Chemistry in Britain, Sokolov in Newsweek, Bernstein in The New Yorker, Maddox in Nature and so forth. Another not selected by Stent, by J. Field, appeared in the Journal of Irreproducible Results, (Vol.17, December 1968, p.53). Because it expresses as well as anything the flavour of Watson's book, it is reproduced above (with the permission of the editor).

Anyone who hasn't yet read The Double Helix should certainly do so, but, even if you own a copy, the additional material in the present volume amply justifies its purchase.

Jerry Donohue is Rhodes-Thompson Professor of Chemistry at the University of Pennsylvania. He spent the academic year 1952-1953 as a Guggenheim Fellow at the Cavendish Laboratory, University of Cambridge. 